\title{
EMPIRICAL THEOLOGY, THE ONLY DYNAMIC REALITY VITALIZING THE SYNERGY BETWEEN ACADEMIC THEOLOGY AND THE CHURCH MISSION IN THE CONTEMPORARY SOCIETY
}

\author{
Assoc. Prof. Ph.D. Ion Marian CROITORU, \\ Faculty of Orthodox Theology and Education Sciences, \\ "Valahia" University, Târgovişte, \\ ROMANIA, \\ E-mail: ioncroitoru@yahoo.fr
}

\begin{abstract}
Spiritual experiences of the Church Saints and the Church teachings are stored in various testimonies (texts, monuments, artistic expressions etc.) about the Church presence and walk in the world. Theology, as a science, under the form of curriculum disciplines, searches for answers, draws conclusions, rehabilitates in a critical manner, studies and interprets all these testimonies or draws arguments from them in the endless dialogue between the Church and the world. The framework of this approach, aimed at studying the Church testimonies, also includes the education offered in the Faculties of Theology. This education transmits to students, on the one hand, knowledge obtained as a fruit of scientific theological research, and, on the other hand, gives them orientation in the Church life, namely in the life according to Jesus Christ's teaching, as it has been lived and experienced by the Saints. Theology, in all its manifestations, represents a Church function, and its space is the Church body, consequently it is related to the Church mission in the world. For this reason, the function of the Church, as place of worship and of healing for man, and the function of School, be it Faculty of Theology or Theological Seminary, are related, being one. Both the Faculty of Theology and the education it provides belong to the vocational domain, which supposes not just external training, namely the appropriation of knowledge, but especially inner training, spiritual transformation and ascension, because the graduates' role, regardless of whether they become clerics or religion teachers etc., is to be a catalyst in the society and to promote a fundamental thing: man's salvation. Due to this thing, the mission of the Faculties of Theology belongs to the framework of the Church mission, and the student's life to the sacramental and liturgical space of the Church. Consequently, the scientific and positive character of academic theology, as theological function of the Church and of her mission, must have in view the aim of the theological education received in a Faculty of Theology, namely, the cultivation of the therapeutic-ascetic function of the Church, in other words, the student's integration in the spiritual life of the Church, which is expressed by the living of the states of purification, illumination and deification, namely his integration in the Church spirituality, where he ought to feel the Saints' communion. All these confirm the reality of empirical theology, as a binder between academic theology and the Orthodox Church mission, but also the relation that ought to exist between the place of worship and the Faculty
\end{abstract}


of Theology, in other words, yet, starting from the latter, the relation between academic theology and Church life or between erudition and the way of living and thinking of the Church. Neglecting the role of empirical theology, as the only dynamic reality vitalizing the synergy between academic theology and the Church mission in the contemporary society, will trigger many negative consequences, by the materialization of certain trends that many theology teachers have drawn our attention to.

Keywords: Church; Orthodoxy; mission; spirituality; academic theology; empirical theology; theology teacher; holy-spiritual life (life in the Holy Spirit); purification; illumination; deification;

1. In the Blessing discourse of His Eminence Teofan, Metropolitan of Moldavia and Bukovina, at the opening of the International Symposium "Dumitru Stăniloae", third edition, entitled Academic Theology and Its Responsibility in the Church Mission, organized in Iași, during the period 14-16 May 2015, which prefaces the proceedings of this Symposium, His Eminence asked himself and, in the same time, addressed to those present at the respective academic reunion certain questions, actually justified: to what extent does today's academic theology manage to be as close as possible to what God wants this so important missionary arm of His Church to be? How is theological education articulated to what the Church Fathers of yore or those contemporary to us have thought? How could one avoid the danger of transforming theologizing into a discourse and into an approach leading to an external reference to God, but also to man and to the world? What is the place occupied by ascesis and the purification from sinful passions in the academic theological approach so that it may not drift away from the word of Saint Gregory the Theologian who says that "we need to purify ourselves and then speak with the Pure One"1 ? How can one fulfil Father Dumitru Stăniloae's word about the study of theology in the spirit of prayer? How can the Faculty of Theology fulfil its mission in the higher education area, so as to bring its specific contribution in the dialogue with the other faculties? Finally, what can be the bishop's expectations from a Faculty of Theology that is under the aegis of the eparchy that he serves and how can these expectations come true so that together bishop and teachers may give a good answer at Christ's dreadful Judgement? ${ }^{2}$

The foundation of these questions consisted, on the one hand, in the differentiation of theology, as an academic research domain, from any other discipline of the university domain, due to the simple reason that its research domain - if we can call it so - goes

\footnotetext{
* This study was first presented in a Romanian variant (Teologia empirică, singura realitate dinamică și vitalizatoare a sinergiei dintre teologia academică și misiunea Bisericii în societatea contemporană) at the International Symposium entitled The Faculty of Theology: academic status and ecclesial mission, organized by the Faculty of Orthodox Theology of Craiova (4-7 October 2017). Later on, I improved this study and I presented it, but under a short form and in English, at The Inaugural Conference Pan-Orthodox Unity and Conciliarity, organized by the International Orthodox Theological Association (IOTA) and the Metropolitanate of Moldavia and Bukovina, Archdiocese of Iași (9-12 January 2019).

${ }^{1}$ His Eminence Teofan paraphrases the text of SAINT GREGORY THE THEOLOGIAN, 1 ó $_{0} \varsigma \varsigma^{1} \Theta$ ', 8-9, in: Patrologia Graeca $(=P G) 36,344$ B, and the translation closer to the original is: for this reason, one has to purify himself first, and then he ought to draw close to the Pure One.

2 † TEOfan, Mitropolitul Moldovei și Bucovinei, "Cuvânt de binecuvântare la deschiderea Simpozionului internațional «Teologia academică și responsabilitatea ei în misiunea Bisericii» (Iași, 14-16 mai 2015)”, in: Pr. ION Vicovan, Pr. PAUl-CEZAR HÂRlăOANu, EMILIAN-IUSTINIAN ROMAN (editors), Teologia academică şi responsabilitatea ei în misiunea Bisericii, Colecția Episteme 22, Ed. Doxologia, Iași, 2016, p. 10.
} 
beyond the framework and the logic of this world, namely: God, deliverance from sinful passions, man's deification, eternal life, all these representing realities that can be neither evaluated, nor known by purely human means and methods and, on the other hand, in the weight and responsibility on the theology teacher's shoulders, called not so much to talk to the students about God, but rather to lead them to finding God, to the meeting with $\mathrm{Him}^{3}$.

2. It is not the aim of this study to analyse the answers that His Eminence Teofan received, by the presentation of the communications made on the occasion of the abovementioned Symposium and of their publication, a mission undertaken, under a certain form, by Father Professor Ion Vicovan, who was at that time and still is at present the Dean of the Faculty of Orthodox Theology of Iași ${ }^{4}$, but I want to reconstitute, as far as I can, one of the answers awaited, within the time granted by the participation to the International Symposium organized, this time, by the Faculty of Theology of Craiova, with a related topic: The Faculty of Theology: academic status and ecclesial mission.

The beginning of my approach starts from the definition of two terms, theology $(\theta \varepsilon o \lambda o \gamma i \alpha)$ and knowledge of God $(\theta \varepsilon o \gamma v \omega \sigma i \alpha)$. As we know, between these two terms, expressing the reality of the holy and spiritual life, there is an interconnection, since theology, in its etymological sense of word or discourse about God, anticipates a knowledge of God, of the one true God, according to the Christian teaching, Who unveils or reveals Himself. This knowledge, according to the Holy Fathers' testimony, can never be the fruit of rational, intellectual, metaphysical research, but of the holy-spiritual experience ${ }^{5}$. In this sense, often cited is Saint Gregory the Theologian, according to whom theologizing is a premise of those put to the test and advanced in contemplation, in other words, in the vision of God, and, first of all, of those who have purified their soul and body or are purifying them, as appropriately as possible 6 . One can draw, therefore, the conclusion, from the narration of this experience of Saint Gregory the Theologian, that the common experience of all the Saints of the one Church, identified with the Orthodox Church, relies on the purification of man in his entirety, soul and body, a state representing the first level of the holy-spiritual life, through which man reaches the second level of this life, illumination, namely the vision of God's glory, under the form of His uncreated Light. This spiritual reality means that only the communion with God, by the work of the uncreated divine grace, beyond any thought or feeling based only on reason or on a sentimentalist kind of living, since God is not identified with the notions held even by the highest theological thought, gives man the quality of theologian, "since theologian is the Saint" theologizing means living the manner of life which is the Orthodoxy, namely acquiring the holy-spiritual life specific to the Orthodoxy, with its three stages or states: purification, illumination and deification. Consequently, the communion with the uncreated divine grace,

\footnotetext{
3 † TEOFAn, Mitropolitul Moldovei și Bucovinei, Cuvânt de binecuvântare, p. 9.

${ }^{4}$ See Pr. Prof. Dr. ION ViCOVAn, "Cuvânt înainte", in: ViCOVAN, HÂRLĂOANU, Roman (editors), Teologia academică, pp. 11-32.

5 Pr. Prof. Dr. Emerit GheOrghe Metallinos, “Teologul în slujirea Bisericii”, translation from Greek and completions of some notes by Lect. Dr. ION MARIAN CROITORU, in: VICOVAN, HÂRLĂOANU, ROMAN (editors), Teologia academică, p. 94.

${ }^{6}$ Saint Gregory the TheOlogian, $\Lambda o ́ \gamma o \varsigma ~ K Z ', 3$, in: PG 36, 13 D.

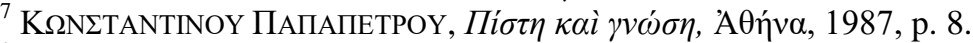

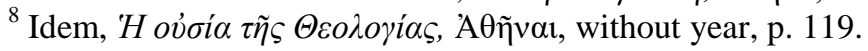


as partaking of the Church mystery, leads man to the entire truth ${ }^{9}$, so that for the Orthodoxy another way of knowing God does not exist ${ }^{10}$.

By virtue of this fact, the Orthodox Christian believer, namely the one confessing Jesus Christ as He established, by His Holy Apostles and Fathers, in His Church, which means that such a believer follows in the Saints'footsteps and walks together with all the Saints, even before getting to experience deification, yet fully living the experience of purification, so, such a believer theologizes in an Orthodox manner, based on the experience of glorification, namely of deification, of the Saints and not due to his eventual rationalistmetaphysical pursuits ${ }^{11}$. When man cultivates his heart's purification, his way opens not onto theological rationalization or a rationalist "theologizing", but onto authentic illumination and theologizing, and, what is more, towards experiencing deification, a state in which God's revelation and [man's] understanding are identical ${ }^{12}$.

3. The Orthodox theology, as holy-spiritual experience of the relation with God, goes beyond any science, by the fact that its subject is multiple, on the one hand, God Who reveals Himself, and, on the other hand, man who ascends, by the work of the uncreated divine grace, to His knowledge, by the method of hesychastic living or of the acquisition of the holy-spiritual life, whereas in the other sciences, the subject is man, who researches and investigates, using specific methods, while the object is God's creation. For this reason, when theology was "coneived" or "received" as a science, catalogued among the positive sciences for its "experimental" and practical character ${ }^{13}$, and cultivated in the academic environment, it was called the highest of all sciences, according, for instance, to the oath of doctor in Theology practiced in the Faculties of Theology from Greece ${ }^{14}$, being, at the same time, considered science in fact and in truth ${ }^{15}$, science of sciences and an immense social conquest of Christianism ${ }^{16}$, which means, according to Father George Metallinos' words, a social recognition of the Church $^{17}$ and of her presence in the higher education environment. In this way, theology received, historically, also the sense of the method of drawing close to God, but also that of research and scientific contribution to the ecclesial reality and the systematic presentation of the Christian faith ${ }^{18}$.

The spiritual experiences of the Saints of the Church and her teachings are stored in different testimonies (texts, monuments, artistic expressions etc.) of the Church presence and walk in the world, as body of the Saviour of the world Jesus Christ. Theology, as a science, under the form of the disciplines that are part of the curriculum, searches [for answers], draws conclusions, critically rehabilitates, studies and interprets all these testimonies or draws from them in the uninterrupted dialogue of the Church with the world. Consequently, the part concerning the historical presence of the Church, which can be researched with the means of science and be perceived rationally, represents the subject of the theological

\footnotetext{
${ }^{9}$ Ioan 16: 13 .

${ }^{10}$ Metallinos, Teologul, p. 94.

${ }^{11}$ Metallinos, Teologul, p. 94.

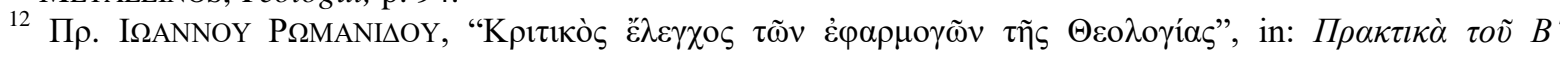

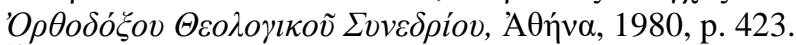

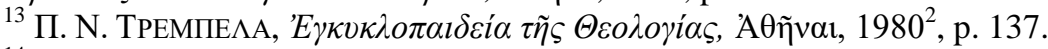

${ }^{14}$ Metallinos, Teologul, p. 94.

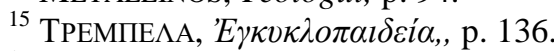

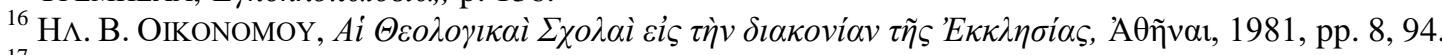

${ }^{17}$ Metallinos, Teologul, p. 94.

${ }^{18}$ Metallinos, Teologul, p. 93, note 1.
} 
scientific research, this research being important not just for the past of the Church, but also for her present in history ${ }^{19}$.

This approach studying the Church testimonies also includes the education offered in the Faculties of Theology, an education, on the one hand, transmitting knowledge from the fruits of the theological scientific research to the students, and, on the other hand, guiding them in the Church life, namely in the life according to Jesus Christ's teaching, as it has been lived and experienced by the Saints.

4. Theology, in all its manifestations, represents a function of the Church, and its space is the Church body, being therefore related to the Church mission in the world. For this reason, the function of the Church, as place of worship, and the function of school, be it Faculty of Theology or Theological Seminary, although today's Seminary, and I refer to the Orthodox Church of Romania, is, to a great extent, laicized, are intertwined, as it has been demonstrated by the lives of the Saints (see, for instance, Saint Photius the Great, who combined the function of teacher and theologian of the Church with that of servant of her, becoming patriarch of Constantinople). Due to this intertwining, theological education must not be religious, but ecclesial, namely it must not be pietist, but spiritual. Given these reasons, the bishop, in whose eparchy there is some theological school and not just him, ought not to remain indifferent to the function of theological education, but also the theological world, in its entirety, cannot disregard the bishop, when the Orthodox conscience has established ${ }^{20}$ that without the bishop no one should do any of the things belonging to the Church ${ }^{21}$. The problem is, however, delicate, because, according to the same Orthodox conscience, this is not just about obedience and attachment to the bishop's person, but especially about loyalty and attachment to the apostolic and patristic tradition of the Church, which, by definition, the bishop has the duty to embody and serve, being the bearer of the apostolic succession, consisting not only of interrupted historical continuity of cheirotonias (ordinations), according to Father George Metallinos, but [also] of the tradition and taking over by the bishop of the manner of existence of the Church, as life in the Holy Spirit. The deviation from this principle signals the appearance of centrifugal tendencies, met as well at the beginning of the $21^{\text {st }}$ century, trends that are not always the fruit of laicization and revolt, but also of shortcomings and exaggerations sometimes coming even from those shepherding the one Church of Jesus Christ, the Saviour of the world ${ }^{22}$. I want this affirmation to be understood not as incrimination, against any cleric, from any level of the Holy Mystery of Priesthood, but only as a warning concerning these tendencies, which can be, skilfully and with pastoral tact, turned into the beneficial work of the Church.

One can note that the Church mission often represents the image of contemporary theology, being, at the same time, also its consequence, since mutual influence is inevitable $^{23}$, and some of the Church shepherds manifest themselves, sometimes, as a despotic authority and a worldly, laicized, power, using behaviour means and methods that deny the Church paternity and spirituality ${ }^{24}$. Given this situation, many are wondering what

\footnotetext{
${ }^{19}$ Metallinos, Teologul, p. 95.

${ }^{20}$ Metallinos, Teologul, p. 97.

${ }^{21}$ Sfântul IgNATIE TEOFOUL, Epistola către Smirneni, 8, 1, in: idem, Epistole, translation, notes and indices by Pr. D. FeCIORU, Părinți și Scriitori bisericești 1, Ed. Institutului Biblic și de Misiune al Bisericii Ortodoxe Române, București, 1979, p. 184.

${ }^{22}$ Metallinos, Teologul, p. 97.

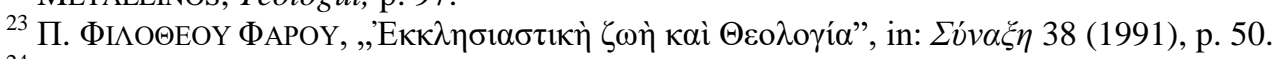

${ }^{24}$ Metallinos, Teologul, p. 103.
} 
the relation between the Church theology and the life of those pastured may be, being noticed, which is actually a sad thing, that theology, as ecclesial word, has substantially stopped moving the soul of the contemporary man, and theological education is taken as a professional answer and solution, which makes one notice, in the case of many graduates of the Faculties of Theology, a marked absence of the spiritual life ${ }^{25}$.

However, even in the case of the theology professors on the university level, be they teaching assistants, lecturers etc., one can note the lack of brotherhood and objectivity, the greedy desire for position and the presence of a behaviour without spiritual milestones, situations that have a negative influence on the student's image on the sense of theological education in his life, as the student sees himself integrated in a tired and self-sufficient higher education area, with few special and enthusiastic professors ${ }^{26}$. By the decisions of certain "commissions" one can note, for instance, that the accent falls more on research and lesser on teaching, and here I refer to the education in the Faculties of Theology from Romania; a difference, somewhat unjust, is made, between the languages of the peoples of Europe and those from other parts of the world, the Westerners' languages being considered first-rank and the Easterners' being seen as second- or even third -rank languages, getting, oddly enough, to cultivate the fashion of preferring to print the fruits of the research of the Romanian academic theology in one of the first-rank languages, because, anyway, in Romanian, considered as a last-rank language, no one would read. One can get, in this rhythm, to forget the writing in Romanian, since many of the young men from Romania prefer a language full of neologisms and agrammatisms. For this reason, it would be good to ask the question, sincerely and manly, with responsibility and commitment, Where is the Romanians' society going to?, in which there is the presence of the Religion Class in schools and the work of so many institutions of pre-university and university theological education, since churches are getting increasingly empty, villages and small towns are increasingly devoid of the youngsters' presence, in the context of the emigration increase and of the observation of a stable demographic decline in Romania, after $1990^{27}$. Under these circumstances, pastoration, reduced in many communities to funerals, commemoration of the dead and social and spiritual care for the elderly ${ }^{28}$, has two facets, one to the rich and another to the poor, being perceptible as well certain innovations introduced in the accomplishment of the Church services ${ }^{29}$.

Therefore, it is precisely the accentuation of the scientific character of academic theology that creates centrifugal tendencies and a distantiation from the real Church mission, because, in the above-mentioned situations, Saint Basil the Great's warning becomes topical: the apostolic traditions are annihilated, modern people's inventions are brought in

\footnotetext{
${ }^{25}$ Metallinos, Teologul, pp. 103-104.

${ }^{26}$ Pr. prof. dr. DANIEL BENGA, "Teologia academică română contemporană. Câteva reflecții autocritice și gânduri pentru o teologie misionară”, in: VICOVAN, HÂRLĂOANU, ROMAN (editors), Teologia academicăa p. 127.

${ }^{27}$ Pr. lect. dr. CRISTIAN SONEA, "Misiunea creștină într-un context eclesial și global în continuă schimbare. Rolul teologiei ortodoxe academice", in: VICOVAN, HÂRLĂOANU, ROMAN (editors), Teologia academică, p. 165.

${ }^{28}$ SONEA, Misiunea creștină, p. 165 .

${ }^{29}$ For instance, the commemoration of the names of the living and of the dead during the Divine Liturgy, but not at Proskomede, but after the reading of the Holy Gospel, during the Litany of Fervent Supplication, out loud. This innovation can take scores of minutes (between 20 to 45 minutes), breaking the unity of the Divine Liturgy and reducing the time allotted to the sermon.
} 
churches; people technologize instead of theologize; the world's wisdom has priority, having pushed aside the praise of the Cross $^{30}$.

These observations are not meant to ignore the importance of the Romanian theological higher education, rich in historical and social milestones, which fully illustrate its missionary character. The problem that emerges is, however, not just about safeguarding this character, but also about strengthening it in front of the challenges coming from the society and the different regimes and types of governance ${ }^{31}$, and also, more recently, following the contact with the Eastern migration phenomenon. An important factor towards the realization of this thing will be the recognition, not just de facto, but also de jure, of the fact that the Faculty of Theology and the education it undertakes belongs to the vocational domain ${ }^{32}$, which supposes not just an exterior training, namely knowledge acquisition, but especially an inner training, in other words, spiritual transformation and ascension, since that the graduates' role, if they become clerics or religion professors etc., is one of catalyst in the society and of promoter of a fundamental thing: man's salvation. Due to this thing, the mission of the Faculties of Theology is part of the Church mission, and the student's life is part of her sacramental and liturgical space.

5. The high form of the Orthodox theology is that of the theologian who is in contemplation, which means continuation of the Pentecost event in history ${ }^{33}$. This continuation is not at all a simple commemoration or reminder of the Pentecost, but the living of this event as personal experience, which means feeling the conscience of belonging to Jesus Christ's Church and living the states of purification, illumination and, where God allows it, deification. Theology from the vision of God is prophetic, and the one who lives it is a prophet and can talk about God's revelation from his own experience, since the fact of prophesying is identified, as it is known, in the Holy Scripture, with the fact of theologizing ${ }^{34}$. Therefore, academic theology does not initiate in the Church experience, but supposes $i t$. The initiation comes by empirical theology, namely by thinking and living the same things with the Prophets, the Apostles, the Fathers, actually, according to Saint Gregory Palamas, with all by whom the Holy Spirit testifies that He has spoken both about God and about His creations ${ }^{35}$. Tragedy intervenes when the appointed teacher of Orthodox Theology functions as a representative of the Church tradition, but, in reality, he is a false prophet, namely a theologian without faith or even completely atheist and immoral, states rebuked both by Father George Metallinos ${ }^{36}$, by the words cited above, and by Father Dumitru Stăniloae ${ }^{37}$, by his words rendered in note, because in the person of such a teacher

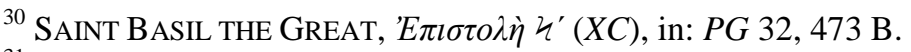

${ }^{31}$ Pr. prof. dr. ȘTEFAN BuCHIU, "Misiunea Facultăților de Teologie Ortodoxă în context contemporan", in: VICOVAN, HÂRLĂOANU, ROMAN (editors), Teologia academică, p. 108.

${ }^{32}$ BuchIU, Misiunea Facultăților, p. 108.

${ }^{33}$ Metallinos, Teologul, p. 93, note 1.

${ }^{34}$ Metallinos, Teologul, p. 94.

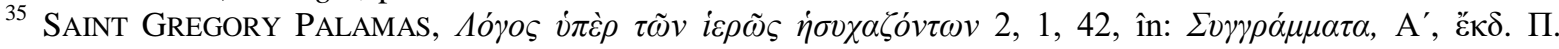

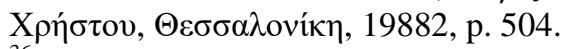

${ }^{36}$ Metallinos, Teologul, p. 98.

${ }^{37}$ Pr. Prof. Dumitru StĂNILOAE, "Reorganizarea facultăților de teologie", in: idem, Cultură și duhovnicie, articles published in Telegraful român, vol. I (1930-1936), edition arranged, introduction and notes by IONDRAGOȘ VLĂDESCU, Ed. Basilica, București, 2012, p. 315: I believe it is not necessary to underline too much the self-obvious absurdity of the thesis that theology is a science that has nothing at all to do with religious life, that you can be the greatest theologian and, at the same time, completely atheist and immoral. Whoever has no religious experience is no theologian either, because he does not understand the contents of the formulas he is
} 
or Church servant are intrinsically denied the science of theology and the Church mission in the world ${ }^{38}$.

The scientific and positive character of academic theology, as theological function of the Church and of her mission, needs to have in view the aim of the theological education received in a Faculty of Theology, namely, the cultivation of the therapeutic-ascetic function of the Church, in other words, the student's integration in the spirituality life of the Church, which is expressed by the living of the states of purification, illumination and deification, namely his integration in the spirituality of the Church, where he ought to feel the communion of the Saints ${ }^{39}$. It is evident that a Faculty of Theology does not make Saints, but, by the theological, pastoral and missionary education that the students receive, it can orient them to the experience of the Saints, source of Theology, and to the method of healingdeification of the human being by the work of the sanctifying and healing divine grace ${ }^{40}$. This role of education can be assumed and exemplified by the theology teacher / scientist with spiritual experience similar to that of the Saints, in other words, by the spiritual or pneumatophoros teacher / professor $^{41}$, who integrates his students, by his courses and his own example, in the practices of the Holy Tradition of the Church, whereas the theology teacher / scientist who keeps himself, with good intentions, only in the spirit of the Orthodox faith, introduces the students theoretically in the Holy Tradition ${ }^{42}$, without convincing them of the reality of the spiritual life.

Actually, the observation of many theology teachers / scientists is that the scientificacademic research of Orthodox theology represents just an introduction to the true theology of the Church ${ }^{43}$ and not a premise of ecclesial theologizing, namely original [theologizing], as revelation, in other words, of divine knowledge $e^{44}$, while the methods of scientific academic theology, as parameters needed in the research process, are different from the empirical theology methods ${ }^{45}$. Consequently, the academic theological research ought to be objective and ought not to pursue anyone's ideology, in order not to get to be unfaithful to the Church treasury, because the theology researcher / teacher is not unbound from

handling. It ought to be mentioned that Father Dumitru Stăniloae refers by the term religious life to the holyspiritual life, belonging to the Orthodox Church.

${ }^{38}$ Metallinos, Teologul, p. 98. About the visions of Father Dumitru Stăniloae on theological education and tuition, by which he recommended, according to Father Ioan Teșu, the synthesis between science and piety, between knowledge and living, between information and prayer, between knowledge and practice, between culture and life in the Holy Spirit, see Pr. prof. univ. dr. IOAN C. TEȘU, "Nevoia și sensul reformei educației religioase și a învățământului teologic în concepția Părintelui Profesor Dumitru Stăniloae”, in: Teologie și viață 23 (89)/1-4 (2013), pp. 145-169 (the text cited above is at p. 161).

${ }^{39}$ Metallinos, Teologul, p. 99.

40 Metallinos, Teologul, p. 99; see also Prof. dr. Chrysostomos A. Stamoulis, "The Contribution of Academic Theology to the Mission of the Church", in: VICOVAn, HÂRLĂOANU, Roman (editors), Teologia academică, p. 117.

${ }^{41}$ Namely a bearer of the Holy Spirit.

${ }^{42}$ Metallinos, Teologul, p. 99.

43 ADRIAN MARINESCU, "Ortodoxie și ortopraxie. Reflecții privind importanța, autoritatea și actualitatea Părinților pentru omul contemporan (II) - Cu un studiu de caz privind fenomenologia patristică şi (re)contextualizarea ei în societatea contemporană", in: Tabor 6/7 (2012), p. 30, note 50.

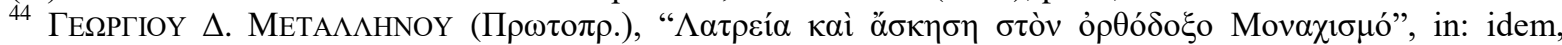

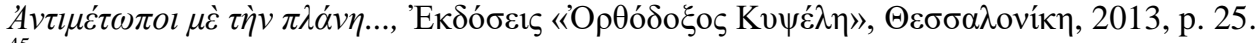

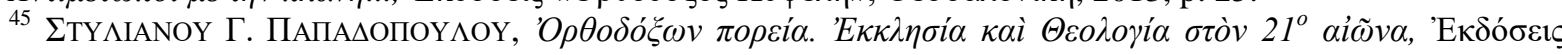

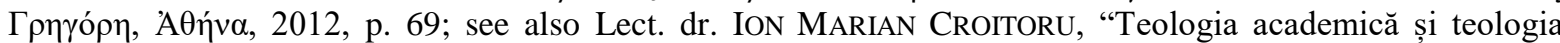
empirică în Biserica Ortodoxă. Congruențe și diferențe”, in: VICOVAN, HÂRLĂOANU, ROMAN (editors), Teologia academică, p. 177. 
faithfulness to the Church life and mission either. Otherwise, the respective theology researcher / teacher gets to be unfaithful to the Church and her head, Who is Jesus Christ the $\operatorname{Lord}^{46}$, and, in this way, out of the desire of vain glory, he drifts away from the Church conscience and blurs the image of the Holy Trinity's charismata's work in the world. The need for faithfulness to the Holy Fathers' way of thinking and living, which also amplifies the theology researcher's / teacher's thinking and brings his academic contributions to the correct approach of the Church teaching, as a whole, is often highlighted by the Holy Church Fathers. Characteristic is Saint John Chrysostom's remark: ... for such is the nature of our mysteries. Thus, in a different state am I and in another state is he who is an unbeliever in relation to them. I hear that Christ gave Himself to be crucified and immediately I admire the love for the people; that one hears and considers the same thing as being powerlessness... That one, hearing about the Resurrection, says that the respective thing is a myth; while I, after having received the evidence through things, I bow to God's oikonomia... On the one hand, the unbelieving, although hearing, seem not to hear; on the other hand, the believers, having the experience by the [Holy] Spirit, see the power of the things that are within $^{47}$. In other words, only those who have been healed spiritually, be they simple believers or theology teachers, can discern the power and the significance of the things hidden in the acts and events from the history of mankind's redemption, by the work of God's Son and Saviour of the world Jesus Christ, namely to know God's Kingdom's mysteries $^{48}$.

At this point in the study, it ought to be remembered the fact that the empirical theology is a medical-therapeutic science and it uses the method of pure science, namely "observation" and "experiment", 49 which means that the Orthodox teaching does not rely on rationalization or imagination ${ }^{50}$. Regarding the scientific but also patristic language, scientific observation focuses on the fact of seeing the uncreated divine grace ${ }^{51}$, namely the uncreated Light, a state of which the Orthodox Christians are reminded during each Divine Liturgy, by the troparion: We have seen the true Light, we have received the heavenly Spirit, we have found the true faith, worshiping the undivided Holy Trinity, Who has saved us ${ }^{52}$. The things included in this troparion are not simple metaphors but spiritual states that man ought to live along his life on Earth, all the more during his participation in the Divine Liturgy $^{53}$, so that observation comes as a result of experiencing the medical-therapeutic education of the Church. Based on this reality, the experiment is equal to entrusting yourself to this education, which leads to personally living the observation and justifies the use of medical terms, but filled with spiritual meanings from a patristic perspective, such as doctor, healing or medical therapy, in relation to the aspects concerning the psychical and bodily, noetic and spiritual healing, a fact for which the Church is called spiritual hospital ${ }^{54}$. All these represent the confirmation of the reality of empirical theology, as a binder between academic theology and the Orthodox Church mission, but also the relation that ought to exist

\footnotetext{
${ }^{46}$ Metallinos, Teologul, p. 100.

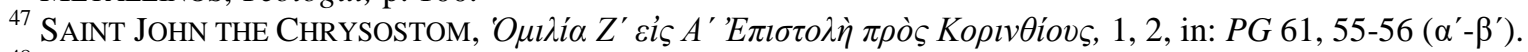

${ }^{48}$ Luke 8: 10.

${ }^{49}$ Metallinos, Teologul, p. 100.

${ }^{50}$ Croitoru, Teologia academică, p. 177.

${ }^{51}$ Metallinos, Teologul, p. 100.

${ }^{52}$ Catavasier sau Octoih mic, Ed. Institutului Biblic și de Misiune al Bisericii Ortodoxe Române, București, 2002, p. 91.

${ }^{53}$ See CROITORU, Teologia academică, p. 189.

${ }^{54}$ Metallinos, Teologul, p. 100.
} 
between the place of worship and the Faculty of Theology, in other words, but starting from the latter, the relation between academic theology and the ecclesial life or between erudition and the way of living and thinking of the Church ${ }^{55}$.

In the empirical or holy-patristic-charismatic theology, considered the only saving reality, man lives the revelation of the knowledge of God and recapitulates, on the personal level, the content of the Pentecost, namely he empirically knows the God-Who-revealedHimself in the framework of the hesychastic way of living and acquires, by means of this experience, the charismata of the Holy Spirit ${ }^{56}$. These charismata represent, by reference to the same scientific language, characteristic of the contemporary society, the scientific spiritual tools necessary to every believer, because, using them, he can contribute both to facing the crisis of perception and of living of the Truth, and to his own salvation and, consequently, to that of his fellows ${ }^{57}$.

According to the Holy Church Fathers, as deified and charismatic people, there is a distinction between man's mind and man's reason or intellect, a fact corresponding to the distinction between empirical theology or empirical knowledge of God and academic theology or the interpretation of the content of faith according to philosophic rationalism. This thing leads, consequently, to the distinction between knowledge of God and knowledge of the surrounding world. By the illumination of his mind by the Holy Spirit, the Orthodox Christian believer acquires the experience of God's uncreated grace into his heart, namely in his entire being, and by reason and thinking, in other words by logical series and analyses, he transfers this experience to those around him. This explains the fact that the theologian, in the proper sense of the word, namely he who has the holy-spiritual experience of the knowledge of God and of the vision of His uncreated Light, can have a knowledge of a thing in a scientific way and become a scientist by knowing the respective science, whereas the scientist, to get to know God, and not just to get to be aware of God's presence in the creation, a fact that he can attain as well by the research specific of his science, needs the help of the Orthodox method of knowing God, a method consisting, as we have mentioned above as well, in the acquisition of the states of purification, illumination and deification, in order to get to live the divine things ${ }^{58}$.

Expressions of this living are the theological notions and dogmas of the faith, which neither mean scientific knowledge of an object, nor describe only something from this world, but are symbols leading man to God, represent the functions of man's relation to God, show the way to salvation. For this reason, their role is not gnostic, in the worldly sense of knowledge, but soteriological, since God's knowledge is not some rational knowledge of an object, but man's salvation, namely his sanctification and deification, which also imply his attainment in history ${ }^{59}$.

One can note, from the Holy Fathers' experiences, that the pedagogical act of the theology and teaching of the Church, perceived, therefore, as a special spiritual communion, implies a serious training different from the lay pedagogical act. It is not enough for the theology teacher / pedagogue to become a participant in and a bearer of the Truth, namely a

\footnotetext{
${ }^{55}$ CROITORU, Teologia academică, p. 189.

${ }^{56}$ CROITORU, Teologia academică, pp. 177-178.

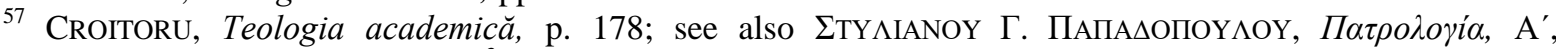

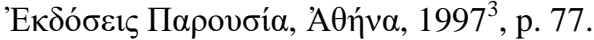

${ }^{58}$ Părintele IOAN ROMANIDIS, Teologia patristică, translation from Greek, notes, bibliographic completions and afterword by ION MARIAN CROITORU, Ed. Bibliotheca, Târgoviște, 2012, pp. 25-31, 62-64; CROITORU, Teologia academică, pp. 180-181.

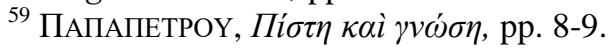


bearer of the Truth revealed in history ${ }^{60}$, and, then, to transfuse to the student this spiritual experience $^{61}$. Saint Basil the Great, for instance, yokes this experience from the life according to God to the one acquired in the daily life, in his case involving as well the intellectual training that he received: Because also the fact of having reached now a certain age, and the fact of having already practiced many things, and certainly also the fact of having taken part, in a satisfactory manner, to one and the other transformation [of life] which educate everyone, have made me experienced in the knowledge of the human things, so that I may indicate precisely the safest way to those who are now just entering life ${ }^{62}$.

As a consequence, theological education, based both on empirical theology, but also on the experience of daily life, does not consist in the search of the perfect thing on an ideatic level, as it happens with philosophy, but in the framework of the historical reality, without, however, identifying this thing with the changing and unstable nature of things ${ }^{63}$; the theology teacher, as a pedagogue-theologian, is not a simple teacher or a passive bearer of scientific-religious knowledge, but he who, having the experience of the Holy Spirit's charismata, and the experience, as Saint Basil the Great puts it, of this world's vanity and of the instability of things ${ }^{64}$, leads the student to the spiritual life, namely to living the rebirth in Jesus Christ ${ }^{65}$; a criterion necessary to the theology teacher consists, therefore, in the experience or the experiences he has and by which he can discern the important things of life and, consequently, stable and permanent, as opposed to the unimportant and transitory ones, which are, more often than not, also destructive ${ }^{66}$. The work of the discernment charisma is not the result of some philosophic thinking or of some academic curiosity ${ }^{67}$, but the fruit of the holy-spiritual life, which indicates the fact that man has acquired divine wisdom, which Saint Basil the Great considers to be the science of the divine but also human things, and of the reasons per $\mathrm{se}^{68}$.

6. Ignoring the role of empirical theology, as the only dynamic reality vitalizing the synergy between academic theology and the Church mission in the contemporary society, will trigger many negative consequences, by the materialization of certain trends to which many theology teachers have drawn the attention during the recent years, such as: the tendency of religious transformation of Theology or of theological education, because of the exacerbated desire of some regarding its modernization and social recognition; the tendency of separating Theology from the life of God's people and its autonomization, no longer taking into account God's work in the Church, and by the Church, in the world; the tendency of copying foreign models ${ }^{69}$ or inventing others, with no practical adaptation to the Orthodox

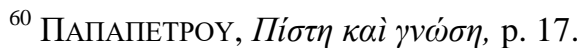

${ }^{61}$ Prof. univ. dr. NICOLAE XIONIS, "Învățător sau pedagog? O abordare teologică a rolului de pedagog al teologului", translation from Greek and notes by Assoc. Prof. dr. ION MARIAN CROITORU, in: Misiune, Spiritualitate, Cultură. Simpozion Internațional. Tinerii și educația religios-morală în contextul lumi contemporane. Contribuția Bisericii la cultura universală, Ed. Valahia University Press, Târgoviște, 2016, p. 226.

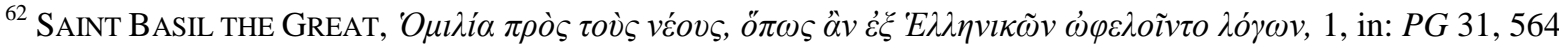
C.

${ }^{63}$ XIONIS, Învătător sau pedagog?, p. 227.

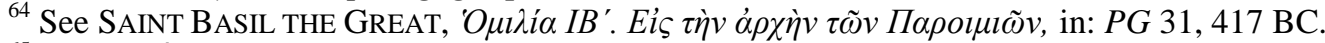

${ }^{65}$ XIONIS, Invăţător sau pedagog?, p. 227.

${ }^{66}$ XIONIS, Invățător sau pedagog?, p. 228.

${ }^{67}$ XIONIS, Învățător sau pedagog?, p. 228.

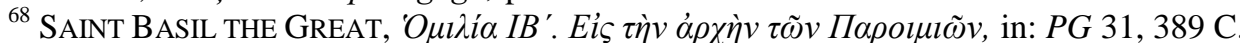

${ }^{69}$ Metallinos, Teologul, p. 104; BuCHIU, Misiunea Facultăţilor, p. 109. 
believers' needs. In relation to this tendency, one can observe the need to rethink the research and teaching methods, in order to maintain an Orthodox theological specific, consisting in the inseparability between theology, worship and spirituality ${ }^{70}$. The accomplishment of this aspect is realized if academic theology shows itself loyal to the divine Revelation and its two organs, the Holy Scripture and the Holy Tradition, by which the discovery of God and the work of the Church become known in the world, so that the mission of the Faculties of Orthodox Theology may represent a part or a segmentmanifestation, according to Father Ștefan Buchiu, which belongs both to the Church and implicitly to the dynamic aspect of the Holy Tradition ${ }^{71}$.

Without criticism and self-criticism ${ }^{72}$ regarding the way theological education takes place, and regarding the forms of expression of academic theology, one can note the risk that academic theology, as it is promoted by the Church clerics and scholars of the present epoch, might attain, according to Father Daniel Benga, the same state of petrification against which our Saviour Christ fought, and the consequence is simple and awful: Look, your house is left to you desolate (Matthew 23: 38) ${ }^{73}$. At the same time, without a culture of debate ${ }^{74}$ and of objective expression, the academic theological discourse deforms theology into ideology and reduces it to a propaganda expressed by a discourse made up of a series of verbal or written clichés. According to Mister Adrian Lemeni, such a theology risks deforming, in fact, it does not inform ${ }^{75}$.

In the context of the cultivation of academic theology, one can note, lately, the consecration of the organization of international and national Symposiums and Conferences by the Faculties of Orthodox Theology of Romania, which is actually a positive thing, yet many shortcomings can be noticed. For instance, the proceedings are printed in a very limited number of copies and often cannot be found even in the great Libraries of the country (The Library of the Academy of Bucharest, The Library of the Holy Synod etc.), or even in the Libraries of the respective Faculties. Consequently, it would be very useful for the organizers to propose to one another an exchange, for these volumes to be found at all the Libraries of the Faculties of Orthodox Theology, in a larger number of copies, in order to be available to the students and even to the teachers, with the evident goal of healing the autism that can be noticed on the level of the communication and appropriation of the latest research in the domain of academic theology. At the same time, the Romanian participants to these reunions demonstrate, increasingly often, a lack of academic seriousness. I do not have in view the quality of the presentations, because they depend on the intellectual training and

\footnotetext{
${ }^{70}$ BuCHIU, Misiunea Facultăților, p. 115.

${ }^{71}$ BuCHIU, Misiunea Facultăților, p. 109. Related to this aspect, academic theology must meet, according to Father Valer Bel, three conditions: 1) be faithful to the Revelation given in Christ and transmitted by the Holy Scripture and the Holy Tradition and lived with no interruption in the Church life; 2) be responsible to the believers of the time when it is made, in the sense that it must be a theology that is actual, making the content of the Revelation accessible to the people of the respective time; 3) be open towards the eschatological future, having the obligation to guide the believers towards their true perfection in that future. Without meeting one of these three conditions, academic theology is insufficient and useless, sometimes even harmful to the Church and the believers [Pr. prof. dr. VALER BEL, "Vocația misionară și doxologică a teologiei academice", in: VICOVAN, HÂRLĂOANU, ROMAN (editors), Teologia academică, p. 153].

${ }^{72}$ BUCHIU, Misiunea Facultăților, p. 113.

${ }^{73}$ BENGA, Teologia academică română contemporană, p. 125.

${ }^{74}$ BENGA, Teologia academică română contemporană, p. 129.

75 Conf. dr. ADRIAN LEMENI, "Exigențe misionare ale învățământului religios și teologic, asumate în relația dintre parohie și școală din contextul actual”, in: ADRIAN LEMENI, pr. DAVID PESTROIU (coord.), Relația dintre parohie și școală în viața și misiunea Bisericii din contextul actual, Ed. Basilica, București, 2015, pp. 114-115.
} 
inner life of each of them, but "the fashion" of doing one's presentation, after which, invoking certain reasons, one withdraws or leaves the respective reunion ${ }^{76}$. In this way, unique opportunities of going deeper into various topics are lost, and the foreigners participating to these events are faced with delicate situations, noticing this "fashion", which tends to become a habit. Another observation refers to the time dedicated to the presentations and, consequently, to the discussions. Every time, some afford to take as much time as they wish and no one dares to draw their attention to the fact that they should limit themselves to the time allotted, others talk only in the presence of sympathizers, while the time limit is strictly imposed on others, which creates the image of the promotion of an academic theology on one's own, in the first case, or of an academic theology based on sympathizers, in the second case, or of a "hasty" academic theology, in the third case, and when the time of discussions comes, the "we-have-no-more-time" is easily invoked, so that so many aspects remain in suspense and are left to the public's free imagination. This shortcoming of the time allotted for discussions reveals, on the one hand, a spirit of self-sufficiency, harmful, however, not just to maintaining an elevated academic atmosphere, but also in relation to the spiritual life, and on the other hand, shows the lack of interest for dialogue and debate, lest the "ideology" of some person or the other not to be disturbed, by taking or clarifying certain positions, all the more so if the respective person is part of the clergy, probably, in order not to harm his "infallibility".

Let us not be amazed of the fact that depending on the quality of the academic theology, namely on the extent to which it is objective, done with seriousness and related to the empirical theology, it will be possible to feel the force of the mission of the Orthodox Church in the Romanian society, and, moreover, it will be possible to note among the Romanian Orthodox Christian believers the presence or the absence of charismata, with a major effect on the good functioning of the Faculties of Theology, namely, the vocations for monastic life and priestly service. These vocations will remain in the people for as long as it will be aware the good work of the Faculties of Theology, together with other factors that are easy to understand, or will be taken away by God, their Giver, if selfishness, particular interests and many other situations will push the approach of academic theology to a distantiation from empirical theology.

The force of academic theology comes not just from the multitude of the studies and books published, but especially from the permanent connection with the empirical theology, forming a common body of the Orthodox Church mission in the world, in order to avoid the evaluation according to which, in the not very far future, the main preoccupation of the Orthodox communities even from the traditionally Orthodox countries of Europe will be the

\footnotetext{
${ }^{76}$ At the beginnings of the organization of these reunions, the situation was completely different. I have my personal experience not just as a speaker, but also as a companion and translator for guests from Greece. One could feel even a joy of the communion and of the spending time together for a period of time as long as possible, all these being accompanied by thirst for knowledge. Yet, as the years have gone by, this enthusiasm has vanished, the academic events have become a routine, giving the impression of their organization for the simple recording of an activity and the "relay race" for taking the floor exceeds any imagination. For example, there have been situations when on the last day of the scientific event remained only the guests from Greece and I, or those who had done their presentations during the first part of the day left the conference hall and the Conference after the midday meal, while, during the second part of the day, the speakers from the first session were no longer in the conference hall after the coffee break, in order to participate to the following session.
} 
survival and not the mission, which would justify the characterization that the Orthodox Church will be in a situation with a glorious past, but an uncertain future ${ }^{77}$.

7. The mission of a theology professor, regardless of the discipline taught, is to rebirth the students to the life in Christ. In order to do this, it is necessary for the teacher himself to be a confessor of God, not just in the sense of someone who talks about Him, but in the patristic sense of someone who first talked to God to then tell about this wonderful conversation to his disciples ${ }^{78}$. This thing means that such a teacher has the empirical theology, in other words, he has the experience of the divine things by the noetic eyes or the eyes of the mind, so that by the work of these spiritual eyes, as a power given by the Holy Spirit and by this power, he sees the all-holy and above-the-material-eyes uncreated Light ${ }^{79}$, and then comes the thinking about the divine things. In this way, one gets to live the words of Saint Gregory Palamas, who says: and listening about the eyes of the soul, which know by this experience the heavenly treasures, you should not imagine that this is about thinking. Because the latter itself, says Saint Gregory Palamas referring to thinking, meditates by itself both to the sensible things, and to the noetical things. Yet, just as with a fortified city that you have not seen yet, if you think about it, you have not experienced it by the fact of thinking about it, it happens just the same with God and the divine things, you do not experience them by the fact of thinking and theologizing about them. And just as it happens with gold, if you do not have it in a sensible manner and do not have it palpably in your hands and do not see it concretely, even if you were to have in your thinking its significance a thousand times, by no means [can you say that] you have or you see or you possessed gold, similarly if you were to think thousands of times about the divine treasures but you do not experience the divine things, and you do not see them with the noetical eyes that are above thinking, then you neither see, nor have, nor really possessed any of the divine things ${ }^{80}$.

Since the theology professor has not just erudition but also holy-spiritual life, namely personal spiritual experience ${ }^{81}$, he grows and changes himself together with his students under the guidance of the Holy Spirit, by a personal relation of communion and of meeting in love, committing not just to the communion of the same answer, but also to the communion of a search for the profound meanings of theology. The professor's commitment is not just temporary, but forever, because at the judgement, in front of Christ, he goes accompanied by his students, uttering, like Joseph in front of Jacob: they are my sons, that God has given me (Genesis 48: 9) ${ }^{82}$. To avoid a self-referential language devoid of any connection with the Holy Fathers' way of thinking and living, the theology professor ought

\footnotetext{
${ }^{77}$ PATRick Johnstone, The Future of the Global Church: History, Trends and Possibilities, InterVarsity Press, Downers Grove, IL, 2011, p. 106; SoNEA, Misiunea creștină, pp. 158, 161. On the level of the year 2011, one can note that in Romania, a country that has an Orthodox majority, the Pentecostals represent the only Christian community which has grown as number. Although the number of the Orthodox converts has increased a lot by comparison with the previous centuries, considering the migration phenomenon, only a part of them continue to remain Orthodox, because the priests do not have enough experience in the pastoral counselling of the converts (SonEA, Misiunea creștină, pp. 163, 166). About the evangelical movements' success in proselytism even among those who are nominally Orthodox, see SonEA, Misiunea creștină, pp. 168-169.

${ }^{78}$ BENGA, Teologia academică română contemporană, p. 136.

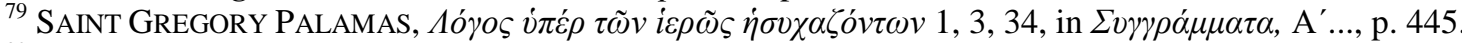

${ }^{80}$ Ibidem.

${ }^{81}$ SONEA, Misiunea creștină, p. 167.

${ }^{82}$ BENGA, Teologia academică română contemporană, p. 136.
} 
not to theologize without the motion of glorification in his heart ${ }^{83}$, because theological education must aim at the essence of theology, namely to train the students in how to become eternal. Actually, theological education does not have in view only the future of time ( $\chi \rho$ óvos), with its three temporal dimensions (past, present and future), but especially the

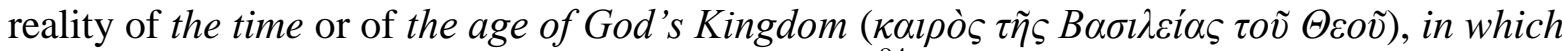
the future is in the present and the present is eternal ${ }^{84}$.

Consequently, theological education has as a purpose the preparation for the real participation, even since the time of the life on earth, to the mystery of God's Kingdom, and reducing it only to the teaching of some notions connected to this approach, recoverable as theological information and, therefore, according to Father Răzvan Ionescu, formalizable by an academic type of knowledge, has as immediate effect the abandonment of the work of the uncreated divine grace for the dry gesture of the transmission of knowledge and the transformation of theology into information leading to the emergence of a new "species" of professor, like, for instance, the thinker, as Father Philotheos Pharos calls it ${ }^{85}$. Seizing this danger, Father Cristian Sonea draws the attention to the fact that such a theological teaching would lead to the shaping of "professional" priests and missionaries, equipped very well with the tools of preaching and confession, yet without the life of the Spirit, which needs to be transmitted by these tools. The danger of our theological schools is that of building only efficient "channels" for the transmission of information of theological nature, without making one feel the work of grace. Without renouncing the academic demands, let us not forget, however, that the essential component of theological training is the Christian priest and missionary's spiritual experience ${ }^{86}$.

When the erudite or academic theologian, namely the theology professor / scientist, has no holy-spiritual life, this representing the fundamental premise of the fact of theologizing in an Orthodox manner and with no mistake ${ }^{87}$, then he has the duty to have the humble living and thinking ( $\tau \alpha \pi \varepsilon i v o ̀ v ~ \varphi \rho o ́ v \eta \mu \alpha)$ and to apply the ecclesial method, as it is recorded in the well-known holy-patristic formula: "being followers of the Holy Fathers

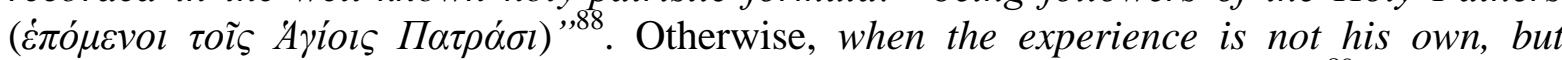
someone else's, the theologian making reflections on it, makes a dead theology ${ }^{89}$.

8. Many times, I have accompanied Greek professors at various Symposiums and Conferences in Romania. More often than not, they would hear, from the Romanian professors of theology, references to Father Dumitru Stăniloae and they would ask me:

${ }^{83}$ GrigorIE Moș, "Vocația doxologică a teologiei”, in: IOAN TUlCAN, CRISTINEL IOJA, FILIP AlBU (coord.), Teologia ca vocație eclezială, pastoral-misionară și dimensiunea sa academică. Astra Muzeum, Sibiu, 2012, pp. 378-379.

SONEA, Misiunea creștină, p. 172. Father Dumitru Stăniloae even makes the mention that for the great reality of time, lived in the Orthodoxy, the word time represents the term for physical measurement for time, while the word age indicates the spiritual living of time (idem, Ortodoxie şi românism, Seria Opere complete VIII, Editura BASILICA, București, 2014, p. 115).

${ }^{85}$ SONEA, Misiunea creștină, p. 172. It is about the Greek Father Philotheos Pharos, an Orthodox priest in Athens.

${ }^{86}$ SONEA, Misiunea creștină, pp. 172-173.

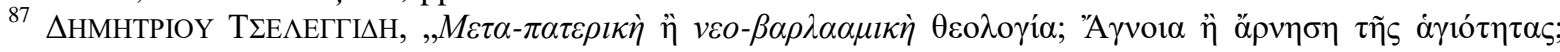

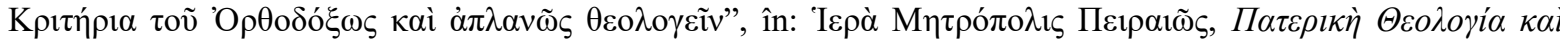

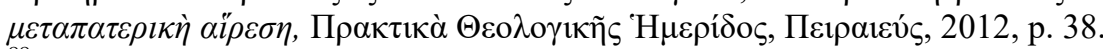

${ }^{88}$ Ibidem, pp. 38, 41; CROITORU, Teologia academică, pp. 183-184.

${ }^{89}$ Pr. Dumitru Stăniloae, Spiritualitate și comuniune în Liturghia ortodoxă, Ed. Institutului Biblic și de Misiune al Bisericii Ortodoxe Române, București, $2004^{2}$, p. 15. 
Father Stăniloae says very well what he says, yet do the Romanian theologians read only him today? Do they ignore his exhortation to read the Holy Fathers or to turn directly to their writings and lives?

The sense of these questions or the interpretation key is that both Father Dumitru Stăniloae in the Romanian theology or in the Orthodox Church of Romania, and Father Georges Florovsky in the Russian theology or Father John Romanidis in the Greek theology had a point in common, namely the exhortation for the people in their time, but also for those after them, to rediscover not just the Holy Fathers' teaching, which would lead to a dry academic theology, but their holy and spiritual experience or experiences, namely for every one of the believers to relive the content of the divine Revelation and the moment of the Pentecost, all the more those teaching the Church doctrine on the academic or university level. In other words, their exhortation is to live empirically the content of the divine Revelation, in order to feel and make visible, and here I refer to the theology professors, the relation between academic theology and Church mission in the contemporary society.

To exemplify this connection, please allow me to present an example entrusted to me, while I was accompanying a theology professor arrived from Greece to Romania, whose father, being a priest, when he was celebrating the Divine Liturgy, would see the Angels and their work in the Holy Altar, during the Divine Eucharist ${ }^{90}$. The respective professor, who is a layman, had to provide an urgent answer to a very important problem, that the Orthodox Church of Greece was faced with, at that moment. He remembered that somewhere, in a Holy Father, he had read something regarding the respective matter, and his memory had retained the name of Saint John Chrysostom. However, he had not been able to identify that passage of Saint John Chrysostom's writings and, in this situation, he prayed that God may send to him someone with a holy-spiritual life, to be sure that he would not go wrong with the solution he was going to give to the respective matter. This attitude shows, therefore, the professor's humility, who did not trust only his memory, on the one hand, and on the other hand, his propensity to prayer. After having finished the prayer, the telephone rang and at the other end of the line was - by divine oikonomia, I shall add - none other but a famous disciple of Father Paisios the Hagiorite ${ }^{91}$.

The two knew each other, and the respective disciple invoked to him the reason that he was coming out of the Holy Mount to Thessaloniki, to solve different problems, and on this occasion, he would like to visit him at his home, because they have something to talk. Great was the joy of the theology professor, and the moment of their meeting took place in a special spiritual atmosphere, full of emotions and special discussions. Among them, the professor also brought into focus the matter of concern for him. That disciple, having the same spiritual state and the same charismata like Saint Paisios, confirmed to him the

\footnotetext{
${ }^{90}$ It is about the illustrious erudite Demetrios Tselengidis, professor of Dogmatics at the Faculty of Theology of Thessaloniki, now retired. His father, Father John, had a holy-spiritual life. Mister Tselengidis told me that one day, when his father was celebrating the Divine Liturgy, and he, being young, was in the pews, he entered, after a while, in the Holy Altar. He sat down piously on one side of the Holy Altar, and the moment of the Divine Liturgy was drawing near to the invocation of the Holy Spirit over the Honourable Gifts. His father waved to him to stand up, but he did not understand the gesture. After the Divine Liturgy came to an end, Father John asked him if he was, maybe, ill. No, he replied. Then Father John told him: Well, did not you see that at that moment, when you were sitting down, all the Angels in the Holy Altar had turned their wings towards the Holy Table?

${ }^{91}$ In a first form of this essay, presented at the Faculty of Orthodox Theology from Craiova, during the International Symposium The Faculty of Theology: academic status and ecclesial mission (4-7 October 2017), I made a confusion between this disciple and Saint Paisios the Hagiorite, a fact clarified following my meeting with Professor Demetrios Tselengidis in Thessaloniki, on 5 June 2018.
} 
solution, and the professor tells him: I think I have read what you are saying in Saint John Chrysostom, but I can no longer find the respective passage. The discussion was taking place by the library of the distinguished professor, exactly where he had the volumes of Saint John Chrysostom's writings from the Greek Patrology, no less than 18 in all. And as the professor was moving his hand next to the respective volumes, not knowing which one to draw out, the respective Father, namely Saint Paisios the Hagiorite's disciple, suggested to him to draw out the volume next to which the professor's hand was at that moment. Drawing it out and putting it in his hands, the volume opens precisely at the passage he was looking for, yet whose content had been related to him as well, a bit earlier, by the Father. The professor looks at him in awe, and the Father tells him: Why are you amazed, the same Holy Spirit, Who was then, is now as well. In other words, those who seek spiritual perfection and come to it, partake of the same content of the divine Revelation and, implicitly, of the Pentecost, by the personal experience of the work of the uncreated divine grace.

To conclude, Jesus Christ's Church, namely the Orthodox Church, being the one, holy, universal and apostolic Church, steps in the world by the steps of yesterday's, today's and tomorrow's Saints, so that the reference to their experiences needs to remain a constant of theological education, because God is not the great absent of man's historical endeavours, on the contrary, He is present in history and the One Who inspires man ${ }^{92}$. For this reason, the Orthodoxy does not represent an epoch of history, but its truth, because it has a past but, what is much more, a present and a future, and its guarantor is the conscience of the Church ${ }^{93}$. In this sense, edifying is an apophthegm of the Egyptian Pateric, which His Eminence Teofan, blessing the works of the Symposium reminded at the beginning of our study, put in the participants' souls. Avva Isidore of Pelusium said that life with no word is of more use than the word with no life. Because life is of use even keeping silent, while the word bothers even when calling out. But if the word and life should meet, they paint the icon of the whole philosophy ${ }^{94}$.

\section{BIBLIOGRAPHY:}

[1] Catavasier sau Octoih mic, Ed. Institutului Biblic și de Misiune al Bisericii Ortodoxe Române, București, 2002.

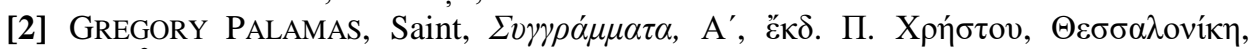
$1988^{2}$.

[3] Johnstone, PAtrick, The Future of the Global Church: History, Trends and Possibilities, InterVarsity Press, Downers Grove, IL, 2011.

[4] LEMENI, ADRIAN / PESTROIU, pr. DAVID (coord.), Relația dintre parohie și școală în viața și misiunea Bisericii din contextul actual, Ed. Basilica, București, 2015.

[5] Misiune, Spiritualitate, Cultură. Simpozion Internațional. Tinerii și educația religios-morală în contextul lumii contemporane. Contribuția Bisericii la cultura universală, Ed. Valahia University Press, Târgoviște, 2016.

[6] Părinți și Scriitori bisericești 1, Ed. Institutului Biblic și de Misiune al Bisericii Ortodoxe Române, București, 1979.

[7] Patericul ce cuprinde în sine cuvinte folositoare ale Sfinților bătrâni, Col. Izvoare duhovnicești 1, Alba Iulia, 1993/1994.

[8] Patrologia Graeca 31, 32, 36, 61.

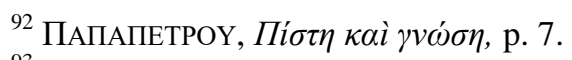

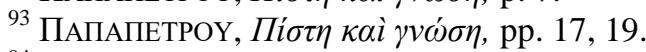

$94+$ TeOfan, Mitropolitul Moldovei și Bucovinei, Cuvânt de binecuvântare, p. 10; see also Pentru Avva Isidor Pelusiotul, 1, in: Patericul ce cuprinde în sine cuvinte folositoare ale Sfinților bătrâni, Col. Izvoare duhovnicești 1, Alba Iulia, 1993/1994, p. 107. 
[9] ROMANIDIS, Părintele IOAN, Teologia patristică, translation from Greek, notes, bibliographic completions and afterword by ION MARIAN CROITORU, Ed. Bibliotheca, Târgoviște, 2012.

[10] Stăniloae, Pr. DuMitru, Spiritualitate și comuniune în Liturghia ortodoxă, Ed. Institutului Biblic și de Misiune al Bisericii Ortodoxe Române, București, 2004².

[11] IDEM, Cultură și duhovnicie, articles published in Telegraful român, vol. I (19301936), edition arranged, introduction and notes by ION-DRAGOȘ VLĂDESCU, Ed. Basilica, București, 2012.

[12] IDEM, Ortodoxie și românism, Seria Opere complete VIII, Editura BASILICA, București, 2014.

[13] TEȘU, Pr. prof. univ. dr. IOAN C., "Nevoia și sensul reformei educației religioase și a învățământului teologic în concepția Părintelui Profesor Dumitru Stăniloae”, in: Teologie și viață 23 (89)/1-4 (2013), pp. 145-169.

[14]TUlCAN, IOAN / IOJA, CRISTINel / AlBU, FILIP (coord.), Teologia ca vocație eclezială, pastoral-misionară și dimensiunea sa academică, Astra Muzeum, Sibiu, 2012.

[15] Vicovan, Pr. ION / HÂRlĂOANu, Pr. PAul-CEZAR / ROMAn, EMILIAN-IUSTINIAN (editors), Teologia academică și responsabilitatea ei în misiunea Bisericii, Colecția Episteme 22, Ed. Doxologia, Iași, 2016.

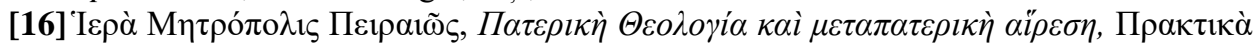

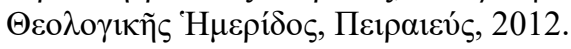

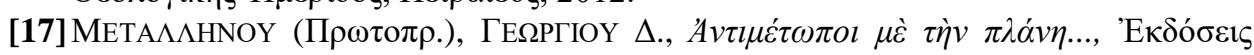

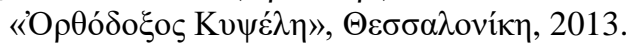

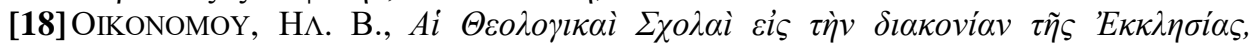
A $\theta \tilde{\eta} v \alpha 1,1981$.

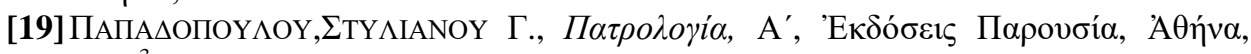
$1997^{3}$.

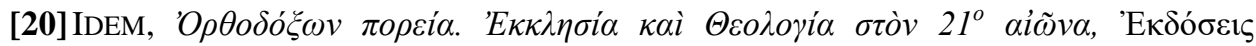

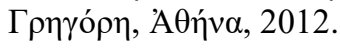

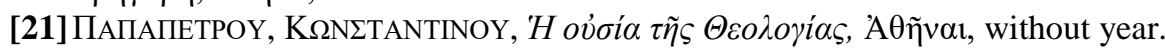

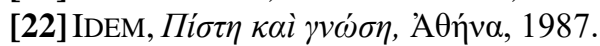

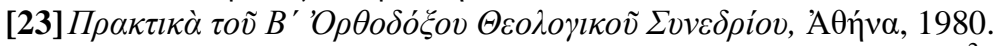

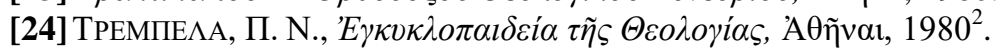

